\title{
Persepsi Dosen Tetap Di Wilayah Jakarta Barat Dan Tangerang Terhadap Penggunaan E-Filling
}

\author{
Sofia Prima Dewi, Merry Susanti, Sufiyati \\ Fakultas Ekonomi, Universitas Tarumanagara, Jakarta \\ Email:sofiad@fe.untar.ac.id
}

\begin{abstract}
This study was made to obtain empirical evidence on the influence of perceptions of security, perceptions of usefulness, perceptions of confidentiality, and perceptions of convenience on the use of e-filling. The method of data collection is done by distributing questionnaires from February to April 2018 to lecturers in the West Jakarta and Tangerang areas. The sampling technique used is simple random sampling. The results showed that perceptions of convenience and perceptions of usefulness have an influence on the use of e-filling while the perception of confidentiality and perception of security have no influence on the use of e-filling.
\end{abstract}

Keywords: use of e-filling, perceptions of security, perceptions of usefulness, perceptions of convenience, perceptions of confidentiality

\begin{abstract}
Abstrak: Penelitian ini dibuat untuk memperoleh bukti empiris mengenai pengaruh persepsi keamanan, persepsi kegunaan, persepsi kerahasiaan, dan persepsi kemudahan terhadap penggunaan $e$-filling. Metode pengumpulan data dilakukan dengan menyebarkan kuesioner dari bulan Februari sampai dengan April 2018 kepada dosen tetap di wilayah Jakarta Barat dan Tangerang. Teknik sampling yang digunakan adalah simple random sampling. Hasil penelitian menunjukkan bahwa persepsi kemudahan dan persepsi kegunaan memiliki pengaruh terhadap penggunaan e-filling sedangkan persepsi kerahasiaan dan persepsi keamanan tidak memiliki pengaruh terhadap penggunaan $e$ filling.
\end{abstract}

Kata kunci: penggunaan e-filling, persepsi keamanan, persepsi kegunaan, persepsi kemudahan, persepsi kerahasiaan

\section{PENDAHULUAN}

Indonesia merupakan negara yang masih dalam tahap melakukan pembangunan dan untuk itu dibutuhkan dana yang tidak sedikit. Sumber dana yang paling potensial menjadi tulang punggung penerimaan negara dalam membiayai dan menyukseskan pembangunan adalah dari penerimaan pajak. Memang tidak mudah untuk mengumpulkan dana dari penerimaan pajak karena dibutuhkan wujud nyata dari peran serta seluruh masyarakat yaitu dengan melakukan pembayaran pajak. Di Indonesia sistem pajak yang berlaku adalah sistem self assessment, dimana masyarakat menghitung, membayar, dan melaporkan sendiri pajaknya. 
Pelaksanaan kewajiban perpajakan setiap tahun akan diakhiri dengan cara melaporkan pajak. Pelaporan pajak ke kantor pajak dilakukan melalui penyampaian surat pemberitahuan (SPT) tahunan pajak penghasilan orang pribadi melalui e-filling. Menurut https://djponline.pajak.go.id e-filling adalah suatu cara untuk melaporkan atau menyampaikan SPT tahunan pajak penghasilan yang dilakukan oleh wajib pajak melalui media elektronik secara real time dan online melalui website penyedia layanan SPT elektronik atau internet pada laman (website) DJP Online. Wajib pajak termasuk dosen tetap, dimana pemberi kerja telah memotong pajak penghasilannya, diwajibkan mengisi SPT tahunan pajak penghasilan orang pribadi dan melaporkannya melalui e-filling ke kantor pajak.

Topik penelitian mengenai faktor-faktor yang mempengaruhi penggunaan e-filling telah banyak dilakukan namun terdapat ketidakkonsistenan dalam penelitian sebelumnya. Penelitian yang dilakukan oleh (Wibisono dan Toly, 2014), (Wowor et al., 2014), (Desmayanti dan Zulaikha, 2012), serta (Poon, 2008) menunjukkan bahwa persepsi keamanan memiliki pengaruh terhadap penggunaan e-filling. Hasil penelitian (Dyanrosi, 2015), (Wibisono dan Toly, 2014), (Laihad, 2013), (Lie dan Sadjiarto, 2013), (Desmayanti dan Zulaikha, 2012), serta (Wiyono, 2008) menjelaskan bahwa penggunaan e-filling dipengaruhi oleh persepsi kegunaan.

Penelitian yang dilakukan oleh (Dyanrosi, 2015), (Wibisono dan Toly, 2014), (Laihad, 2013), (Lie dan Sadjiarto, 2013), (Desmayanti dan Zulaikha, 2012), serta (Noviandini, 2012) menunjukkan bahwa penggunaan e-filling dipengaruhi oleh persepsi kemudahan. Penelitian (Maryani, 2016) menyimpulkan bahwa persepsi kemudahan tidak berpengaruh atas penggunaan e-filling. Penelitian (Wibisono dan Toly, 2014), (Wowor et al., 2014), (Desmayanti dan Zulaikha, 2012), dan (Poon, 2008) menunjukkan bahwa persepsi kerahasiaan memiliki pengaruh terhadap penggunaan e-filling. Berdasarkan uraian di atas dan ketidakkonsistensian hasil-hasil penelitian sebelumnya maka dilakukan kembali penelitian mengenai pengaruh persepsi keamanan, persepsi kegunaan, persepsi kemudahan, dan persepsi kerahasiaan terhadap penggunaan $e$-filling.

\section{KAJIAN TEORI}

\section{Penggunaan $e$-Filling}

Dalam rangka memenuhi aspirasi wajib pajak mengenai tata cara pelaporan SPT baik itu SPT masa maupun SPT tahunan, maka Direktur Jenderal Pajak mengeluarkan Keputusan Direktur Jenderal Pajak Nomor KEP-88/PJ./2004 pada tanggal 14 Mei 2004 tentang penyampaian Surat Pemberitahuan (SPT) secara elektronik. Dengan berhasilnya program e-SPT pada tanggal 24 Januari 2005, maka Direktorat Jenderal Pajak mengeluarkan produk e-filling sebagai produk inovasi dari perkembangan teknologi informasi.

E-filling adalah sistem pelaporan atau penyampaian SPT secara elektronik yang dilakukan melalui sistem on-line dan realtime (Wahyuni et al., 2015). Pada e-filling tidak lagi diperlukan dokumen fisik berupa kertas-kertas. Direktorat Jenderal Pajak melakukan pembaharuan dalam sistem perpajakan agar meminimalkan tingkat risiko dan bersifat lebih praktis adalah dengan mengirimkan dokumen dalam bentuk arsip elektronik. Di layanan pajak online arsip elektronik telah tersedia dan akan siap memandu para 
pengguna layanan. Dengan demikian kegiatan pengisian dan pengiriman SPT tahunan dapat dilakukan oleh Wajib Pajak dengan mudah dan efisien.

Tujuan layanan e-filling adalah untuk memberikan fasilitas pelaporan atau penyampaian SPT secara elektronik kepada wajib pajak. Wajib pajak baik orang pribadi maupun badan dapat melakukan hal ini dari rumah maupun tempat bekerja ataupun tempat umum lainnya, baik dewngan menggunakan computer ataupun laptop sepanjang terdapat jaringan internet. Tentunya ini akan dapat membantu wajib pajak guna menghemat biaya serta mengurangi waktu yang dibutuhkan untuk melaporkan atau menyampaikan SPT secara benar dan tepat waktu ke kantor pajak. Di pihak lain, kantor pajak juga akan menerima laporan SPT dengan lebih cepat dan kegiatan administrasi tentunya akan lebih ramping. Layanan e-filling ini dapat diakses kapan saja dan dimana saja, sehingga penyampaian SPT melalui e-filling akan lebih efisien dan efektif karena dapat dilakukan setiap saat selama 24 jam dalam 7 hari (Wahyuni et al., 2015).

Langkah awal agar bisa menerapkan e-filling adalah melakukan pengajuan permohonan aktivasi Electronic Filing Identification Number ke Kantor Pelayanan Penyuluhan dan Konsultasi Perpajakan (KP2KP). Electronic Filing Identification Number (EFIN) merupakan nomor identitas yang dikeluarkan oleh Direktorat Jenderal Pajak bagi pembayar pajak yang menggunakan media elektronik dalam penyampaian SPTnya. Wajib pajak orang pribadi harus mengajukan permohonan aktivasi EFIN oleh wajib pajak yang bersangkutan dan tidak diperbolehkan untuk diwakilkan kepada pihak lain. Di pihak lain, bagi wajib pajak badan dapat melakukan permohonan aktivasi EFIN melalui pengurus yang mewakili wajib pajak badan, tanpa harus wajib pajak badan sendiri yang melakukannya.

Langkah berikutnya setelah mendapatkan EFIN adalah mendaftarkan diri di laman Direktorat Jenderal Pajak Online atau laman penyedia layanan SPT elektronik dengan cara membuat akun pada layanan pajak online. Apabila akun sudah diaktifkan maka wajib pajak dapat melakukan login ulang dengan mengisi Nomor Pokok Wajib Pajak dan password nya. Selanjutnya adalah melakukan pengisian serta pengiriman SPT tahunan melalui $e$-filling ke kantor pajak.

Direktorat Jenderal Pajak menyediakan e-filling dalam rangka memudahkan sekaligus meningkatkan pelayanan kepada wajib pajak yang akan melaksanakan hak dan memenuhi kewajiban perpajakan, namun dalam penerapannya kendala yang dihadapi adalah intensitas penggunaan e-filling pada wajib pajak baik wajib pajak orang pribadi maupun wajib pajak badan sangat minim.

\section{Persepsi Keamanan}

Hal penting dalam suatu sistem adalah aspek keamanan. Keamanan didefinisikan sebagai seberapa besar kemungkinan ancaman akan terealisasi dibandingkan dengan usaha yang telah dilakukan untuk mencegah terjadinya ancaman tersebut (Bruck et al., 2015). Persepsi keamanan didefinisikan sebagai kepercayaan konsumen bahwa informasi pribadi mereka tidak akan dimanipulasi oleh pihak lain (Flavian and Guinaliu, 2006). Secara teknis persepsi keamanan akan menjamin kerahasiaan, tanpa pencatatan transaksi, integritas dan otentifikasi. Persepsi keamanan mempengaruhi tingkah laku pemakai sistem informasi (Nepomuceno et al., 2012). 
Keamanan didefinisikan sebagai tingkat kehilangan atau pencurian data, dalam sistem informasi, yang rendah atau sangat kecil (Mujiyati et al., 2016). Sistem informasi yang aman terjadi jika data pengguna atau pemakai dapat disimpan dengan aman oleh sistem informasi (Wibisono dan Toly, 2014). Dengan demikian, kesempatan pihak lain untuk menyalahgunakan data pengguna akan semakin kecil. Apabila keamanan data di dalam sistem $e$-filling terjamin maka minat perilaku wajib pajak yang menggunakan $e$ filling akan meningkat (Wahyuni et al., 2015).

\section{Persepsi Kegunaan}

Biasanya persepsi kegunaan dijadikan sebagai riset atas penggunaan teknologi informasi. Hal ini dikarenakan sebelum teknologi informasi tersebut diterapkan atau diaplikasikan, terlebih dahulu harus dipastikan mengenai apakah pemakai atau pengguna teknologi akan menerima atau menolak (Mujiyati et al., 2016). Apabila pemakai menerima teknologi tersebut, hal ini menunjukkan bahwa pemakai menganggap teknologi informasi tersebut berguna bagi si pemakai sehingga teknologi informasi tersebut akan berhasil diterapkan. Pendapat yang sama juga diungkapkan oleh (Wahyuni et al., 2015) dimana wajib pajak akan menggunakan e-filling apabila mereka menganggap e-filling akan berguna dalam pelaporan SPT pajak penghasilan. Apabila wajib pajak semakin tertarik menggunakan teknologi informasi maka jumlah wajib pajak yang menggunakan $e$ filling juga akan bertambah.

\section{Persepsi Kemudahan}

Persepsi kemudahan penggunaan didefinisikan sebagai tidak adanya kesulitan yang akan dihadapi saat memanfaatkan teknologi. Persepsi kemudahan terkait dengan teknologi informasi sebagai anggapan si pemakai atau pengguna bahwa teknologi informasi mudah untuk dipahami dan digunakan. Apabila suatu teknologi informasi dirancang sedemikian rupa sehingga pemakai atau pengguna dapat menggunakannya dengan mudah berarti sistem tersebut dianggap berkualitas (Wibisono dan Toly, 2014).

Apabila wajib pajak memandang e-filling sebagai sistem yang mudah untuk digunakan dalam memenuhi kewajiban perpajakannya, maka wajib pajak akan menggunakan kembali sistem tersebut di masa yang akan datang (Maryani, 2016). Pemerintah berharap kemudahan penggunaan e-filling akan menertibkan administrasi perpajakan dan menciptakan transparansi perpajakan. Pendapat yang sama juga dinyatakan oleh (Wahyuni et al., 2015) yaitu bila pengguna menganggap sistem $e$-filling dapat mengurangi waktu dan tenaga maka pengguna akan menggunakan sistem tersebut secara terus-menerus.

\section{Persepsi Kerahasiaan}

Kerahasiaan didefinisikan sebagai terjaminnya semua informasi pribadi dari pengguna sistem informasi (Mujiyati et al., 2016). Sistem informasi harus dapat menjaga kerahasiaan data pengguna sehingga tidak dapat diakses oleh pihak lain dengan bebas (Wibisono dan Toly, 2014). Kerahasiaan sekarang ini menjadi masalah yang paling penting terkait dengan penggunaan informasi melalui internet (Featherman et al., 2010).

Penelitian (Nepomuceno et al., 2012) menunjukkan bahwa persepsi kerahasiaan memainkan peranan yang penting terkait dengan pemakaian sistem online. Apabila 
kerahasiaan data pelaporan pajak oleh pengguna di dalam sistem $e$-filling terjamin maka minat pengguna untuk menggunakan sistem e-filling akan meningkat (Wahyuni et al., 2015).

\section{Penelitian Terdahulu dan Pengembangan Hipotesis}

(Poon, 2008) melakukan penelitian mengenai penerapan jasa $e$-banking di Malaysia dengan sampel sebanyak 324 responden. Hasil penelitian menunjukkan bahwa aksesibilitas, desain, kenyamanan, dan konten memiliki pengaruh terhadap kepuasan pengguna, sedangkan privasi dan keamanan tidak memiliki pengaruh terhadap kepuasan pengguna.

Penelitian (Desmayanti dan Zulaikha, 2012) mengenai faktor-faktor yang mempengaruhi penggunaan fasilitas e-filling oleh wajib pajak badan sebagai sarana penyampaian SPT masa secara online dan realtime menggunakan sampel berupa wajib pajak badan yang telah menyampaikan SPT masa dengan menggunakan e-filling sebanyak 72 wajib pajak yang terdapat di kota Semarang. Hasil penelitian menunjukkan bahwa complexity, perceived ease of use, perceived usefulness, readiness technology taxpayer information, dan security and privacy memiliki pengaruh terhadap penggunaan fasilitas $e$ filling.

(Noviandini, 2012) melakukan penelitian mengenai pengaruh persepsi kebermanfaatan, persepsi kemudahan penggunaan, dan kepuasan wajib pajak terhadap penggunaan $e$-filling di kota Yogyakarta. Responden yang digunakan adalah sebanyak 99 wajib pajak badan yang menggunakan e-filling. Penelitian (Noviandini, 2012) menunjukkan bahwa kepuasan wajib pajak, persepsi kebermanfaatan, dan persepsi kemudahan penggunaan memiliki pengaruh terhadap penggunaan $e$-filling.

Penelitian (Laihad, 2013) mengenai pengaruh perilaku wajib pajak terhadap penggunaan e-filling wajib pajak di kota Manado menggunakan sampel sebanyak 50 orang. Hasil penelitian menunjukkan bahwa persepsi kegunaan dan persepsi kemudahan memiliki pengaruh terhadap penggunaan $e$-filling, sementara sikap terhadap perilaku tidak memiliki pengaruh.

(Lie dan Sadjiarto, 2013) melakukan penelitian di kota Kediri mengenai faktorfaktor yang mempengaruhi minat perilaku wajib pajak orang pribadi dalam menggunakan e-filling. Sampel penelitian ini adalah sebanyak 167 wajib pajak orang pribadi yang menggunakan $e$-filling di kota Kediri. Hasil penelitian menunjukkan bahwa faktor sosial, kesukarelaan, persepsi terhadap kegunaan, dan persepsi kemudahan memiliki pengaruh terhadap minat perilaku wajib pajak dalam menggunakan $e$-filling.

Penelitian (Wibisono dan Toly, 2014) menggunakan sampel sebanyak 75 wajib pajak badan. Penelitian ini menyimpulkan bahwa keamanan dan kerahasiaan, persepsi kegunaan, kesiapan teknologi informasi, dan persepsi kemudahan memiliki pengaruh terhadap minat wajib pajak badan dalam penggunaan $e$-filling di kota Surabaya.

(Wowor et al., 2014) melakukan penelitian mengenai faktor-faktor yang mempengaruhi perilaku wajib pajak badan untuk menggunakan e-filling dengan sampel sebanyak 91 wajib pajak badan di kota Manado. Hasil penelitian menunjukkan bahwa persepsi keamanan dan kerahasiaan, serta persepsi pengalaman memiliki pengaruh terhadap perilaku penggunaan $e$-filling, sedangkan persepsi kecepatan tidak memiliki pengaruh terhadap perilaku penggunaan $e$-filling . 
Penelitian (Dyanrosi, 2015) adalah mengenai perilaku wajib pajak orang pribadi terhadap minat perilaku menggunakan $e$-filling. Hasil penelitian dengan sampel sebanyak 99 WP-OP di kota Malang menjelaskan bahwa usia (age), sikap terhadap penggunaan (attitude toward using), kompleksitas (complexity), pengalaman menggunakan (experience), dan persepsi kemudahan penggunaan (perceived easy of use) memiliki pengaruh terhadap minat perilaku wajib pajak dalam menggunakan $e$-filling sebagai sarana pelaporan pajaknya.

(Wahyuni et al., 2015) melakukan penelitian mengenai pengaruh persepsi kegunaan, keamanan dan kerahasiaan, kemudahan, dan kecepatan terhadap intensitas perilaku dalam penggunaan e-filling (studi pada WP-OP di KPP pratama Pekanbaru Senapelan). Hasil penelitian dengan sampel sebanyak 98 responden menunjukkan bahwa persepsi keamanan dan kerahasiaan, persepsi kecepatan, dan persepsi kemudahan memiliki pengaruh terhadap intensitas perilaku dalam penggunaan e-filing sedangkan persepsi kegunaan tidak memiliki pengaruh terhadap intensitas perilaku dalam penggunaan $e$-filling.

Penelitian (Maryani, 2016) mengenai pengaruh persepsi kemudahan pemakaian, teknologi informasi, dan kepuasan pemakai terhadap penggunaan e-filling menggunakan kuesioner sebanyak 122 dari 7 fakultas, pascasarjana, dan rektorat. Hasil penelitian menunjukkan bahwa kepuasan pemakai dan teknologi informasi memiliki pengaruh terhadap penggunaan $e$-filling, sedangkan persepsi kemudahan pemakaian tidak berpengaruh atas penggunaan $e$-filling.

(Mujiyati et al., 2016) melakukan penelitian mengenai faktor-faktor yang mempengaruhi penggunaan $e$-filling terhadap $100 \mathrm{WP}-\mathrm{OP}$ yang terdaftar di KPP Surakarta dan Sukoharjo. Hasil penelitian menunjukkan bahwa keamanan dan kerahasiaan, kesukarelaan, kompleksitas, kesiapan informasi teknologi wajib pajak, persepsi kegunaan, pengalaman, persepsi kemudahan memiliki pengaruh terhadap penggunaan $e$-filling .

Berikut ini disajikan model penelitian yaitu:

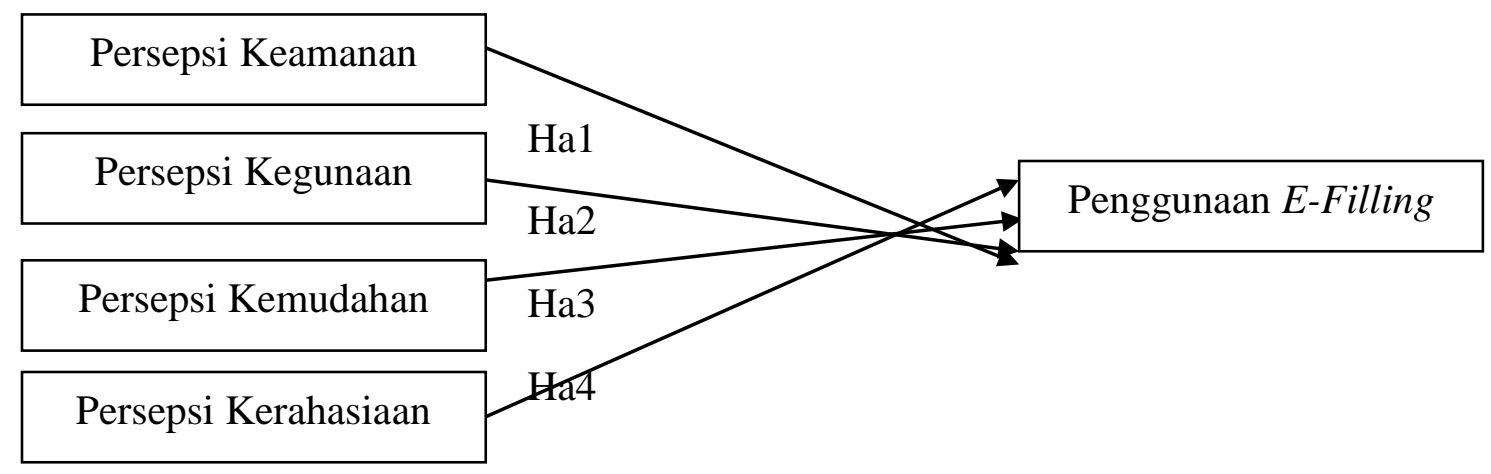

Gambar 1. Model Penelitian

Berdasarkan uraian di atas maka perumusan hipotesis adalah sebagai berikut:

Ha1: Persepsi keamanan berpengaruh terhadap penggunaan $e$-filling.

Ha2: Persepsi kegunaan berpengaruh terhadap penggunaan $e$-filling.

Ha3: Persepsi kemudahan berpengaruh terhadap penggunaan $e$-filling .

Ha4: Persepsi kerahasiaan berpengaruh terhadap penggunaan $e$-filling . 


\section{METODE}

\section{Populasi dan Metode Pengambilan Sampel}

Dosen tetap di Jakarta Barat dan Tangerang yang dijadikan sebagai populasi dalam penelitian ini. Probability sampling digunakan untuk menarik sampel dan teknik yang dipakai adalah simple random sampling. Sebanyak 200 dosen tetap yang dibagikan kuesioner dalam penelitian ini.

\section{Operasionalisasi Variabel Penelitian}

Dalam penelitian ini variabel dependen adalah penggunaan e-filling. Variabel independen dalam penelitian ini terdiri dari persepsi keamanan, persepsi kegunaan, persepsi kemudahan, dan persepsi kerahasiaan. Operasionalisasi variabel diukur dengan menggunakan beberapa indikator yang mengacu pada penelitian terdahulu. Variabelvariabel yang diukur dalam penelitian ini adalah:

1. Penggunaan $e$-filling.

Indikator yang digunakan sesuai dengan penelitian (Desmayanti dan Zulaikha, 2012):

a. Saya selalu menggunakan $e$-filling setiap kali melaporkan pajak.

b. Saya berkehendak untuk melanjutkan menggunakan $e$-filling di masa depan.

c. Saya akan selalu menggunakan e-filling untuk melaporkan pajak karena mempunyai fitur yang membantu pekerjaan saya.

2. Persepsi keamanan.

Indikator yang digunakan sesuai dengan penelitian (Poon et al., 2008) serta (Desmayanti dan Zulaikha, 2012):

a. Pemanfaatan layanan pelaporan pajak dengan menggunakan e-filling adalah aman bagi saya.

b. Saya tidak khawatir dengan masalah keamanan e-filling.

c. Permasalahan tingkat keamanan dalam e-filling tidak mempengaruhi saya dalam memanfaatkan layanan pelaporan pajak.

d. Menurut saya, username sangat penting.

e. Menurut saya, password sangat penting.

f. Saya tidak pernah menyimpan login id di dalam komputer saya.

g. Saya tidak pernah menyimpan password di dalam komputer saya.

3. Persepsi kegunaan.

Indikator yang digunakan sesuai dengan penelitian (Desmayanti dan Zulaikha, 2012):

a. Penerapan $e$-filling dapat meningkatkan performa pelaporan pajak saya.

b. Penerapan e-filling dapat meningkatkan efektivitas pelaporan pajak saya.

c. Penerapan $e$-filling dapat menyederhanakan proses pelaporan pajak saya.

d. Penerapan $e$-filling dapat meningkatkan produktivitas saya.

4. Persepsi kemudahan.

Indikator yang digunakan sesuai dengan penelitian (Desmayanti dan Zulaikha, 2012):

a. Saat menggunakan e-filling, saya dapat mengoperasikannya sesuai dengan kebutuhan saya.

b. Saya merasa $e$-filling sangat fleksibel untuk digunakan.

c. Interaksi saya dengan $e$-filling jelas. 
d. Interaksi saya dengan e-filling mudah dipahami.

e. Saya jarang mengalami kebingungan saat menggunakan interaksi saya dengan $e$ filling.

f. Tampilan e-filling mudah untuk dibaca sehingga saya mudah untuk memahaminya.

g. Mudah bagi saya untuk mempelajari bagaimana cara menggunakan e-filling.

h. Mudah bagi saya untuk menggunakan $e$-filling secara terampil.

i. Saya tidak melakukan kesalahan-kesalahan berlanjut ketika mengoperasikan $e$ filling.

j. Saya tidak membutuhkan usaha yang keras untuk dapat berinteraksi dengan $e$ filling.

k. Saya tidak merasa $e$-filling merupakan suatu sistem yang rumit.

1. Saya mudah berinteraksi dengan sistem $e$-filling saat melaporkan pajak.

5. Persepsi kerahasiaan.

Indikator yang digunakan sesuai dengan penelitian (Poon et al., 2008) serta (Desmayanti dan Zulaikha, 2012):

a. Pemanfaatan layanan pelaporan pajak dengan menggunakan e-filling dapat memberikan tingkat jaminan kerahasiaan yang tinggi.

b. Saya percaya bahwa $e$-filling dapat menjaga kerahasiaan saya.

c. Permasalahan tingkat kerahasiaan dalam $e$-filling tidak mempengaruhi saya dalam memanfaatkan layanan pelaporan pajak.

d. Saya percaya bahwa fiskus akan menjamin kerahasiaan data pribadi saya yang dilaporkan melalui $e$-filling.

e. Saya percaya bahwa sistem e-filling selalu di-up-date.

\section{Teknik Pengumpulan Data}

Kuesioner disebarkan dari bulan Februari sampai dengan bulan April 2018 kepada 200 dosen tetap yang mengajar di Universitas wilayah Jak-Bar dan Tangerang secara tertutup, dimana jawaban sudah ditentukan terlebih dahulu oleh peneliti, sehingga responden tidak dapat memberikan jawaban yang lain.

\section{Teknik Pengolahan Data}

Analisis kuantitatif yaitu analisis regresi Ordinary Least Square digunakan dalam penelitian ini. Penelitian ini menggunakan model regresi sebagai berikut:

$$
\mathrm{PE}=\mathrm{a}+\mathrm{b} 1 \mathrm{PA}+\mathrm{b} 2 \mathrm{PG}+\mathrm{b} 3 \mathrm{PM}+\mathrm{b} 4 \mathrm{PR}+\mathrm{e}
$$

dimana: $\mathrm{PE}=$ Penggunaan $e$-filling, $\mathrm{a}=$ Konstanta, $\mathrm{b} 1-4=$ Koefisien regresi masingmasing variabel, $\mathrm{PA}=$ Persepsi keamanan, $\mathrm{PG}=$ Persepsi kegunaan, $\mathrm{PM}=$ Persepsi kemudahan, $\mathrm{PR}=$ Persepsi kerahasiaan, dan e $=$ Error .

Apabila seluruh uji asumsi klasik terpenuhi maka langkah selanjutnya adalah melakukan pengujian hipotesis penelitian dengan menggunakan tingkat kesalahan sebesar 5\%. Uji statistik yang dilakukan adalah uji F dan uji t.

\section{HASIL DAN PEMBAHASAN}

\section{Pemilihan Sampel}


Terlebih dahulu, dilakukan penyebaran kuesioner kepada 20 responden. Hal ini dilakukan untuk menguji apakah calon responden dapat memahami isi kuesioner. Setelah pre-test, selanjutnya kuesioner disebar untuk melakukan uji validitas dan reliabilitas.

Kuesioner akan didistribusikan pada dosen di Universitas wilayah Jak-Bar dan Tangerang dari bulan Februari sampai dengan bulan April 2018. Sebanyak 200 kuesioner disebarkan kepada dosen dan ternyata kuesioner yang kembali hanya 56\% yaitu sebanyak 112 responden. Dari 112 responden terdapat 8 responden yang tidak melengkapi kuesioner sehingga dikeluarkan dari sampel. Dengan demikian total yang digunakan adalah 104 responden. Penelitian ini menggunakan PASW Statistics versi 16.00.

\section{Pengujian Validitas dan Reliabilitas \\ Validitas}

Pengujian validitas tiap butir dilakukan dengan menggunakan bantuan perangkat lunak PASW Statistics versi 16.00. Jika corrected item-total correlation tiap butir menunjukkan nilai lebih besar dari 0,3 maka butir tersebut dinyatakan valid. Berikut adalah hasil pengujian validitas.

Tabel 1. Hasil Pengujian Validitas Persepsi Keamanan

\begin{tabular}{ccc}
\hline Variabel & $\begin{array}{c}\text { Corrected Item- } \\
\text { Total Correlation }\end{array}$ & Keterangan \\
\hline Persepsi Keamanan Butir 1 & 0,522 & Valid \\
Persepsi Keamanan Butir 2 & 0,627 & Valid \\
Persepsi Keamanan Butir 3 & 0,494 & Valid \\
Persepsi Keamanan Butir 4 & 0,379 & Valid \\
Persepsi Keamanan Butir 2 & 0,455 & Valid \\
Persepsi Keamanan Butir 3 & 0,382 & Valid \\
Persepsi Keamanan Butir 4 & 0,379 & Valid \\
\hline
\end{tabular}

Corrected item-total correlation tiap butir di tabel atas menunjukkan nilai lebih besar dari 0,3 sehingga setiap butir dapat dinyatakan valid.

Tabel 2. Hasil Pengujian Validitas Persepsi Kegunaan

\begin{tabular}{ccc}
\hline Variabel & $\begin{array}{c}\text { Corrected } \\
\text { Item- } \\
\text { Total } \\
\text { Correlation }\end{array}$ & Keterangan \\
\hline Persepsi Kegunaan Butir 1 & 0,761 & Valid \\
Persepsi Kegunaan Butir 2 & 0,766 & Valid \\
Persepsi Kegunaan Butir 3 & 0,709 & Valid \\
Persepsi Kegunaan Butir 4 & 0,758 & Valid \\
\hline
\end{tabular}

Setiap butir dapat dinyatakan valid karena tabel di atas menunjukkan bahwa corrected item-total correlation tiap butir memiliki nilai $>0,3$.

Tabel 3. Hasil Pengujian Validitas Persepsi Kemudahan

\begin{tabular}{ccc}
\hline Variabel & $\begin{array}{c}\text { Corrected Item- } \\
\text { Total Correlation }\end{array}$ & Keterangan \\
\hline
\end{tabular}




\begin{tabular}{lll}
\hline Persepsi Kemudahan Butir 1 & 0,799 & Valid \\
Persepsi Kemudahan Butir 2 & 0,750 & Valid \\
Persepsi Kemudahan Butir 3 & 0,757 & Valid \\
Persepsi Kemudahan Butir 4 & 0,815 & Valid \\
Persepsi Kemudahan Butir 5 & 0,729 & Valid \\
Persepsi Kemudahan Butir 6 & 0,781 & Valid \\
Persepsi Kemudahan Butir 7 & 0,793 & Valid \\
Persepsi Kemudahan Butir 8 & 0,654 & Valid \\
Persepsi Kemudahan Butir 9 & 0,723 & Valid \\
Persepsi Kemudahan Butir 10 & 0,752 & Valid \\
Persepsi Kemudahan Butir 11 & 0,829 & Valid \\
Persepsi Kemudahan Butir 12 & 0,805 & Valid \\
\hline
\end{tabular}

Tabel 3. menunjukkan bahwa corrected item-total correlation tiap butir memiliki nilai > 0,3 sehingga setiap butir tersebut dapat digunakan dalam penelitian ini.

Tabel 4. Hasil Pengujian Validitas Persepsi Kerahasiaan

\begin{tabular}{ccc}
\hline Variabel & $\begin{array}{c}\text { Corrected Item- } \\
\text { Total Correlation }\end{array}$ & Keterangan \\
\hline Persepsi Kerahasiaan Butir 1 & 0,776 & Valid \\
Persepsi Kerahasiaan Butir 2 & 0,812 & Valid \\
Persepsi Kerahasiaan Butir 3 & 0,616 & Valid \\
Persepsi Kerahasiaan Butir 4 & 0,790 & Valid \\
Persepsi Kerahasiaan Butir 5 & 0,643 & Valid \\
\hline
\end{tabular}

Tabel 4. menunjukkan bahwa corrected item-total correlation tiap butir memiliki nilai lebih besar dari 0,3 sehingga setiap butir tersebut dapat dinyatakan valid.

Tabel 5. Hasil Pengujian Validitas Penggunaan E-Filling

\begin{tabular}{ccc}
\hline Variabel & $\begin{array}{c}\text { Corrected Item- } \\
\text { Total Correlation }\end{array}$ & Keterangan \\
\hline Penggunaan E-Filling Butir 1 & 0,730 & Valid \\
Penggunaan E-Filling Butir 2 & 0,692 & Valid \\
Penggunaan E-Filling Butir 3 & 0,660 & Valid \\
\hline
\end{tabular}

Tabel 5. menunjukkan bahwa corrected item-total correlation tiap butir memiliki nilai lebih besar dari 0,3 sehingga setiap butir tersebut dinyatakan valid.

\section{Reliabilitas}

Jika nilai koefisien Cronbach Alpha lebih besar atau sama dengan 0,6 maka data dikatakan reliabel. Berikut adalah hasil pengujian reliabilitas:

Tabel 6. Hasil Uji Reliabilitas Variabel Penelitian

\begin{tabular}{lcc}
\hline \multicolumn{1}{c}{ Variabel } & Alpha & Keterangan \\
\hline Penggunaan E-Filling & 0,830 & Reliabel \\
Persepsi Keamanan & 0,739 & Reliabel \\
Persepsi Kegunaan & 0,884 & Reliabel
\end{tabular}



Persepsi Kemudahan
0,951
0,887
Reliabel
Persepsi Kerahasiaan

Tabel 6. menunjukkan bahwa nilai koefisien Cronbach Alpha lebih besar dari 0,6 sehingga data dapat dinyatakan reliabel.

\section{Statistik Deskriptif}

Karakteristik responden yang dijadikan sebagai subjek dalam penelitian ini akan dijelaskan berdasarkan fakultas, jenis kelamin, tingkat pendidikan, dan usia. Tabel di bawah ini menunjukkan karakteristik responden berdasarkan fakultas.

Tabel 7. Karakteristik Responden Berdasarkan Fakultas

\begin{tabular}{lcc}
\hline Fakultas & Frekuensi & Persentase \\
\hline Ekonomi & 101 & 97 \\
Hukum & 1 & 1 \\
Teknik & 1 & 1 \\
Teknologi Informasi & 1 & 1 \\
\hline
\end{tabular}

Tabel di atas menunjukkan jumlah responden dari Fakultas Ekonomi sebanyak 97\% yaitu 101 orang, Fakultas Teknologi Informasi sejumlah 1\% yaitu 1 responden, Fakultas Teknik sebanyak $1 \%$ yaitu 1 orang, dan Fakultas Hukum sebanyak $1 \%$ yaitu 1 orang. ini.

Karakteristik responden berdasarkan jenis kelamin dapat dilihat pada tabel di bawah

Tabel 8. Karakteristik Responden Berdasarkan Jenis Kelamin

\begin{tabular}{ccc}
\hline Jenis Kelamin & Frekuensi & Persentase \\
\hline Pria & 43 & 41,3 \\
Wanita & 61 & 58,7 \\
Total & 104 & 100 \\
\hline
\end{tabular}

Tabel 8 menggambarkan karakteristik responden sebanyak 104 responden berdasarkan jenis kelamin terbagi atas pria sejumlah 43 responden $(41,3 \%)$ dan wanita sebanyak 61 orang $(58,7 \%)$. berikut:

Karakteristik responden berdasarkan tingkat pendidikan adalah sebagai berikut

Tabel 9. Karakteristik Responden Berdasarkan Tingkat Pendidikan

\begin{tabular}{ccr}
\hline Tingkat Pendidikan & Frekuensi & Persentase \\
\hline S1 & 6 & 5,8 \\
S2 & 88 & 84,6 \\
S3 & 10 & 9,6 \\
\hline
\end{tabular}

Berdasarkan tabel di atas diketahui bahwa sebanyak 5,8\% yaitu 6 orang memiliki tingkat pendidikan S1, sebanyak $84,6 \%$ yaitu 88 orang memiliki tingkat pendidikan S2, dan yang memiliki tingkat pendidikan S3 sebanyak 9,6\% yaitu 10 orang.

Karakteristik responden berdasarkan usia adalah sebagai berikut:

Tabel 10. Karakteristik Responden Berdasarkan Usia

\begin{tabular}{ccc}
\hline Usia & Frekuensi & Persentase \\
\hline $25-34$ tahun & 20 & 19,2
\end{tabular}




\begin{tabular}{lrr}
$35-44$ tahun & 43 & 41,3 \\
$45-54$ tahun & 39 & 37,5 \\
$>54$ tahun & 2 & 1,9 \\
\hline
\end{tabular}

Berdasarkan tabel di atas diketahui bahwa sebanyak 19,2\% yaitu 20 orang yang berusia 25 - 34 tahun, sebanyak $41,3 \%$ yaitu 43 orang yang berusia antara 35 - 44 tahun, sebanyak $37,5 \%$ yaitu 39 orang yang berusia antara $45-54$ tahun, dan sebanyak 1,9\% yaitu 2 orang yang berusia $>54$ tahun.

\section{Analisis dan Pembahasan}

Pengujian hipotesis dilakukan setelah uji asumsi klasik telah terpenuhi seluruhnya. Pengujian hipotesis untuk menperoleh bukti secara empiris mengenai pengaruh persepsi keamanan, persepsi kegunaan, persepsi kemudahan, dan persepsi kerahasiaan terhadap penggunaan $e$-filling. Hasil uji F dapat dilihat pada Tabel 11.

$\frac{\text { Tabel 11. Hasil Uji F }}{\text { Sig. }}$

Tabel 11. menunjukkan nilai signifikansi sebesar 0,000 (lebih kecil dari 0,05) sehingga Ho ditolak dan Ha diterima. Hal ini berarti minimal ada satu variabel bebas yang dapat mempengaruhi variable terikat (penggunaan e-filling). Selanjutnya dilakukan uji $\mathrm{t}$ sehingga dapat diketahui variabel bebas mana saja yang dapat mempengaruhi penggunaan e-filling. Berikut adalah hasil uji t.

Tabel 12. Hasil Uji t

Unstandardized

Sig.

Coefficients Beta

\begin{tabular}{ccc}
\hline Konstanta & 0,857 & 0,011 \\
PA & 0,020 & 0,871 \\
PG & 0,336 & 0,007 \\
PM & 0,400 & 0,001 \\
PR & 0,026 & 0,782 \\
\hline
\end{tabular}

Model regresi yang digunakan dalam penelitian ini yaitu:

$$
\mathrm{PE}=0,857+0,020 \mathrm{PA}+0,336 \mathrm{PG}+0,400 \mathrm{PM}+0,026 \mathrm{PR}+\mathrm{e}
$$

dimana: $\mathrm{PE}=$ Penggunaan $e$-filling, $\mathrm{PA}=$ Persepsi keamanan, $\mathrm{PG}=$ Persepsi kegunaan, $\mathrm{PM}=$ Persepsi kemudahan, $\mathrm{PR}=$ Persepsi kerahasiaan, dan $\mathrm{e}=$ Error .

Tabel 12. menunjukkan bahwa persepsi keamanan terhadap penggunaan $e$-filling memiliki nilai p-value sebesar 0,871. Nilai ini melebihi 0,05 yang berarti H1 (hipotesis kesatu) tidak diterima. Dengan demikian, persepsi keamanan tidak memiliki pengaruh terhadap penggunaan $e$-filling.

Hasil penelitian ini sejalan dengan penelitian (Poon, 2008), namun tidak sejalan dengan penelitian (Mujiyati et al., 2016), (Wahyuni et al., 2015), (Wibisono dan Toly, 2014), (Wowor et al., 2014), serta (Desmayanti dan Zulaikha, 2012). Tidak 
berpengaruhnya persepsi keamanan terhadap penggunaan $e$-filling dikarenakan para dosen merasa bahwa e-filling tidak dapat menjamin keamanan data mereka sehingga para dosen cenderung menghindari penggunaan $e$-filling .

Tabel 12. menunjukkan bahwa persepsi kegunaan terhadap penggunaan e-filling mempunyai nilai signifikansi sebesar 0,007 . Nilai ini lebih kecil dari 0,05 yang berarti $\mathrm{H} 2$ (hipotesis kedua) diterima. Dengan demikian, persepsi kegunaan memiliki pengaruh terhadap penggunaan $e$-filling.

Hasil penelitian ini konsisten dengan penelitian (Mujiyati et al., 2016), (Wibisono dan Toly, 2014), (Laihad, 2013), (Lie dan Sadjiarto, 2013), serta (Desmayanti dan Zulaikha, 2012), namun tidak konsisten dengan penelitian (Wahyuni et al., 2015). Berpengaruhnya persepsi kegunaan terhadap penggunaan $e$-filling dikarenakan para dosen menganggap teknologi informasi tersebut berguna sehingga para dosen cenderung menggunakan $e$-filling.

Tabel 12. menunjukkan bahwa persepsi kemudahan terhadap penggunaan $e$-filling memiliki nilai signifikansi sebesar 0,001. Nilai ini lebih kecil dari 0,05 yang berarti H3 (hipotesis ketiga) diterima. Dengan demikian, persepsi kemudahan memiliki pengaruh terhadap penggunaan $e$-filling.

Hasil penelitian ini konsisten dengan penelitian (Mujiyati et al., 2016), (Dyanrosi, 2015), (Wahyuni et al., 2015), (Wibisono dan Toly, 2014), (Laihad, 2013), (Lie dan Sadjiarto, 2013), (Desmayanti dan Zulaikha, 2012), (Noviandini, 2012), dan (Poon, 2008). Di sisi lain hasil penelitian ini tidak konsisten dengan penelitian (Maryani, 2016). Berpengaruhnya persepsi kemudahan terhadap penggunaan e-filling dikarenakan para dosen merasa bahwa dengan mudahnya teknologi dalam $e$-filling menyebabkan para dosen lebih memilih untuk menggunakan $e$-filling.

Tabel 12. menunjukkan bahwa persepsi kerahasiaan terhadap penggunaan e-filling memiliki nilai signifikansi sebesar 0,782 . Nilai ini lebih besar dari 0,05 yang berarti $\mathrm{H} 4$ (hipotesis keempat) tidak diterima. Dengan demikian, persepsi kerahasiaan tidak memiliki pengaruh terhadap penggunaan $e$-filling.

Hasil penelitian ini konsisten dengan penelitian (Poon, 2008), namun tidak konsisten dengan penelitian (Mujiyati et al., 2016), (Wahyuni et al., 2015), (Wibisono dan Toly, 2014), (Wowor et al., 2014), serta (Desmayanti dan Zulaikha, 2012). Tidak berpengaruhnya persepsi kerahasiaan terhadap penggunaan e-filling dikarenakan para dosen merasa bahwa e-filling tidak dapat menjamin kerahasiaan data mereka sehingga para dosen cenderung menghindari penggunaan $e$-filling.

\section{PENUTUP}

Persepsi kegunaan dan persepsi kemudahan memiliki pengaruh terhadap penggunaan e-filling yang dilakukan oleh dosen di Jakarta Barat dan Tangerang. Persepsi keamanan dan persepsi kerahasiaan tidak memiliki pengaruh terhadap penggunaan $e$ filling yang dilakukan oleh dosen di Jakarta Barat dan Tangerang.

Secara keseluruhan, walaupun persepsi kemudahan dan persepsi kegunaan memiliki pengaruh terhadap penggunaan $e$-filling, namun para dosen masih merasa enggan menggunakan $e$-filling. Hal ini disebabkan para dosen merasa jika mereka menggunakan e-filling maka keamanan dan kerahasiaan data mereka tidak terjamin. Keterbatasan 
penelitian ini adalah hanya menggunakan sampel sebanyak 104 responden dosen di wilayah Jakarta Barat dan Tangerang. Untuk penelitian berikutnya hendaknya responden diperbanyak dengan cara melakukan penyebaran kuesioner ke responden selain di wilayah Jakarta Barat dan Tangerang.

\section{DAFTAR RUJUKAN}

Brück, Tilman, Olaf J. de Groot, and Neil T. N. Ferguson. (2015) Measuring Security In Understanding Terrorism. Published online: 09 Mar 2015; 69-95. (Retrieved from: https://doi.org/10.1108/S1572-8323(2014)0000022009).

Desmayanti, Esy dan Zulaikha. (2012) "Faktor-Faktor Yang Mempengaruhi Penggunaan Fasilitas e-Filling Oleh Wajib Pajak Sebagai Sarana Penyampaian SPT Masa Secara Online dan Realtime (Kajian Empiris di Wilayah Kota Semarang)”. Diponegoro Journal of Accounting 1 (1): 1-12.

Direktorat Jenderal Pajak. (2004) Keputusan Direktur Jenderal Pajak Nomor KEP88/PJ/2004 tentang Penyampaian Surat Pemberitahuan Secara Elektronik. Jakarta: Direktorat Jenderal Pajak.

Dyanrosi, Aulia. (2015) “Analisis Perilaku Wajib Pajak Orang Pribadi Terhadap Minat Perilaku Menggunakan e-Filling”. Jurnal Ilmu Sosial dan Ilmu Politik 4 (2): 354365.

Featherman, Mauricio S., Anthony D. Miyazaki, and David E. Sprott. (2010) "Reducing online privacy risk to facilitate e-service adoption: the influence of perceived ease of use and corporate credibility". Journal of Services Marketing 24 (3): 219-229.

Flavian, Carlos and Miguel Guinaliu. (2006) "Consumer Trust, Perceived Security And Privacy Policy: Three Basic Elements of Loyalty To A Web Site". Industrial Management \& Data Systems 106 (5): 601-620.

Laihad, Risal C.Y. (2013) "Pengaruh Perilaku Wajib Pajak Terhadap Penggunaan eFilling Wajib Pajak di Kota Manado". Jurnal EMBA 1 (3): 44-51.

Lie, Ivana dan Arja Sadjiarto. (2013) "Faktor-Faktor Yang Mempengaruhi Minat Perilaku Wajib Pajak Untuk Menggunakan e-Filling". Tax and Accounting Review 3 (2): 115.

Maryani, Ay. (2016) "Faktor-Faktor Yang Mempengaruhi Penggunaan e-Filling: Studi Pada UIN Syarif Hidayatullah Jakarta". Akuntabilitas Jurnal Ilmu Akuntansi 9 (2): 161-172.

Mujiyati, Karmila, dan Septiyara Wahyuningtyas. (2016) Faktor-Faktor Yang Mempengaruhi Penggunaan e-Filling Bagi Wajib Pajak Orang Pribadi (Studi Empiris Pada Wajib Pajak di KPP Sukoharjo dan KPP Surakarta). Seminar Nasional dan The $3^{\text {rd }}$ Call For Syariah Paper. Syariah Paper Accounting FEB UMS: 419-430.

Nepomuceno, Marcelo Vinhal, Michel Laroche, Marie-Odile Richard, and Axel Eggert. (2012) "Relationship Between Intangibility And Perceived Risk: Moderating Effect Of Privacy, System Security And General Security Concerns". Journal of Consumer Marketing 29 (3): 176-189.

Noviandini, Nurul Citra. (2012) "Pengaruh Persepsi Kebermanfaatan, Persepsi Kemudahan Penggunaan, dan Kepuasan Wajib Pajak Terhadap Penggunaan eFilling Bagi Wajib Pajak di Yogyakarta”. Jurnal Nominal 1 (1): 15-22. 
Poon, Wai Ching. (2008) 'Users' Adoption of e-Banking Services: The Malaysian Perspective". Journal of Business And Industrial Marketing 23 (1): 59-69.

Wahyuni, Resky, Kirmizi, dan Rusli. (2015) "Pengaruh Persepsi Kegunaan, Kemudahan, Keamanan dan Kerahasiaan, dan Kecepatan Terhadap Intensitas Perilaku Dalam Penggunaan e-filling (Studi Pada Wajib Pajak Orang Pribadi di Kantor Pelayanan Pajak Pratama Pekanbaru Senapelan)". Jom Fekon 2 (2): 1-15.

Wibisono, Lisa Tamara dan Agus Arianto Toly. (2014) "Analisis Faktor-Faktor Yang Mempengaruhi Minat Wajib Pajak Dalam Penggunaan e-Filling di Surabaya". Tax and Accounting Review 4 (1): 1-15.

Wiyono, Adrianto Sugiarto. (2008) "Evaluasi Perilaku Penerimaan Wajib Pajak Terhadap Penggunaan e-Filling Sebagai Sarana Pelaporan Pajak Secara Online dan Realtime". Jurnal Riset Akuntansi Indonesia 11 (2): 117-132.

Wowor, Ricky Alfiando, Jenny Morasa, dan Inggriani Elim. (2014) "Analisis FaktorFaktor Yang Mempengaruhi Perilaku Wajib Pajak Untuk Menggunakan e-Filling". Jurnal EMBA 2 (3): 1340-1349. 